\title{
Financial Features of Systemically Important Banks Operation in Modern Conditions
}

\author{
Elvira Ildarovna Bulatova ${ }^{1}$ \& Ekaterina Vladimirovna Ipatova ${ }^{1}$ \\ ${ }^{1}$ Kazan Federal University, Kazan, Russia \\ Correspondence: Elvira Ildarovna Bulatova, PhD in Economics, Associate Professor, Chair of Financial Markets and \\ Financial Institutions, Institute of Management, Economics and Finance, Kazan, Russia. Tel: 7-917-390-0555.
}

Received: September 2, 2020

Accepted: October 12, 2020

Online Published: December 24, 2020

doi:10.5430/ijfr.v12n1p23

URL: https://doi.org/10.5430/ijfr.v12n1p23

\begin{abstract}
The modern banking system is one of the key elements of any national economic system that influences the formation of economic processes. In this regard, it is important to identify the main elements of the banking system that have the greatest impact on the modern economy. The article reveals the financial and distinctive features of modern systemically important credit organizations of the Russian Federation. The authors of the article, based on the structural and dynamic analysis of the credit organizations indicators system, identified the main trends in the banking system development, highlighting the role of systemically important banks in this process. In the course of the analysis, based on the reporting data on the development of the Russian banking system for 2016-2019, the connection between the dynamics of the systemically important credit institutions development and the banking system as a whole was determined. The main conclusions presented in the article can be used in scientific and practical activities in order to strengthen and develop banking regulation and supervision of the largest Russian banks.
\end{abstract}

Keywords: systemically important credit organizations, banking sector, central bank, banking regulation and supervision, bank assets, deposits of the population, funds placed

\section{Introduction}

The current stage of the banking sector development is characterized by stricter standards of state regulation and supervision, an increase in the level of concentration, increased requirements for the capital quality, and an increase in the overall level of risk of the activity (Kahraman, 2020). The Basel Committee on banking supervision supports the regulatory development by developing approaches and summarizing the practice of measures against major banks.

In the world practice, a range of instruments of different nature and degree of impact is used to regulate and supervise the activities of systemically important banks. These activities include mechanisms for resolving the insolvency of financial institutions, establishing additional requirements for capital and liquidity, introducing a tax on system significance, and others.

To date, there are two levels of regulators of systemically important credit institutions (SICI):

1. National: Central banks and other national regulatory bodies that provide supervision and control over local systemic credit institutions (the Bank of Russia, the Federal reserve, the German Federal Bank, the Bank of England, and others).

2. Supranational: international organizations involved in the recommendations and measures development for SICI (financial stability Board, Bank for international settlements, Basel Committee on banking supervision (BCBS), international monetary Fund).

The national level takes precedence over international organizations and Central banks have the right to independently develop their own methods of identifying SICI or set the level of their capital adequacy. The supranational level encourages cooperation between national regulators and major international organizations in developing common approaches to reducing systemic risks.

An essential step in improving the macroprudential regulation of SICI was the principles of banking supervision practices revision related to systemically important global institutions, presented in 2014 by the Basel Committee on banking supervision. As part of these recommendations, additional changes were implemented to the basic principles 
of regulation:

1) Supervisory authorities should strengthen information exchange for more effective supervision of international banking groups;

2) Supervisory registration authorities of the parent Bank and the host country should establish mechanisms and communication channels for the timely exchange of information;

3) Structure of the Supervisory authority should be modified to improve oversight for these groups.

As a result of the changes made, the regulation of the SICI activities includes the following measures:

- Reducing losses (recovery plans, effective rehabilitation, bankruptcy prevention, strengthening of market infrastructure, commissions and taxes);

- Reducing losses from the crisis (intensity of supervision, disclosure of information and anti-crisis plans);

- Reducing the significance and define criteria for systemically significant intermediaries (restrictions on the size, organizational structure, and scale of activity).

Reducing the importance of financial institutions themselves is done within the framework of increasing capital adequacy requirements and the taxes introduction - contributions to special funds.

The following measures are being taken in relation to Russian SICI:

- Improving the efficiency of supervision;

- Effective resolution of financial institutions' involvement;

- Additional capital adequacy requirements;

- Increasing the stability of systemically important financial market infrastructure facilities.

The need to regulate systemically important banks is also explained by the contagion effect, in which trends inherent in the banking sector extend to both the public sector and the real sector of the economy. Loss of confidence in systemically essential banks gives rise to a fall in demand for banking services in the entire banking sector of the country, reduces confidence in public authorities. This issue also results in a reduction in demand in the markets of goods and services, and the real economy has a lack of financial resources, there is a difficulty with payment systems, increases the propensity to save, decreases investment activity.

Issues of functioning and regulation of systemically important banks are the most critical issues of the banking system, both in Russian and international experience. The reason is that they affect not only other credit and financial organizations but also spread through the contagion effect on the real sector of the economy.

\section{Methods}

As part of an analytical study of the systemically important banks place and role in the economy of the Russian Federation, it is necessary to:

1) Evaluate the SICI activities for four indicators (Federal law of 22.07.2015) :

- Size of the credit institution, expressed as total assets;

- Connection with credit and other financial organizations within the limits of the placed funds;

- Connection with credit and other financial organizations within the framework of raised funds;

- Volume of individual deposits.

2) Analyze the SICI development dynamins and assess the contribution of the activities of the banking sector.

Structural and dynamic analysis of these indicators will help to determine how much funds and resources are concentrated in systemically important banks, as well as the dependence of the banking sector on the activities of these banks (Bulatova, 2019).

According to the Decree 3737-U, systemically important credit organizations have the right to choose the valuation of assets: according to the 101 reporting form, or according to the 806 forms (balance sheet) (Federal law of 22.07.2015).

\section{Results and Discussion}

At the first stage of the study, the dynamics of SICI total assets were analyzed using the data in Table 1. Data on the SICI assets are presented based on annual banking reports (form 806). 
Table 1. Assets of Russian systemically important banks dynamics (Overview of the banking sector of the Russian Federation \& Directory of credit organizations)

\begin{tabular}{|c|c|c|c|c|c|c|c|c|}
\hline \multirow{2}{*}{$\begin{array}{l}\text { Name of the credit } \\
\text { institution }\end{array}$} & \multicolumn{2}{|c|}{01.01 .2016} & \multicolumn{2}{|c|}{01.01 .2017} & \multicolumn{2}{|c|}{01.01 .2018} & \multicolumn{2}{|c|}{01.01 .2019} \\
\hline & $\begin{array}{l}\text { Volume, } \\
\text { bln rub }\end{array}$ & Share, $\%$ & $\begin{array}{l}\text { Volume, } \\
\text { bln rub }\end{array}$ & Share, $\%$ & $\begin{array}{l}\text { Volume, } \\
\text { bln rub }\end{array}$ & Share, $\%$ & $\begin{array}{l}\text { Volume, } \\
\text { bln rub }\end{array}$ & Share, $\%$ \\
\hline Sberbank & 22706,9 & 27,4 & 21721,1 & 27,1 & 23158,9 & 27,2 & 26899,9 & 28,6 \\
\hline VTB & 9394,6 & 11,3 & 9429,0 & 11,8 & 9631,2 & 11,3 & 13642,2 & 14,5 \\
\hline Gazprombank & 4952,8 & 6,0 & 4748,2 & 5,9 & 5268,3 & 6,2 & 6151,6 & 6,5 \\
\hline Rosselkhoznadzor & 2510,9 & 3,0 & 2679,3 & 3,3 & 3077,5 & 3,6 & 3338,4 & 3,5 \\
\hline Alfa-bank & 2058,6 & 2,5 & 2246,8 & 2,8 & 2495,7 & 2,9 & 3215,9 & 3,4 \\
\hline Moscow credit bank & \multicolumn{4}{|c|}{ is not systematically significant } & 1829,9 & 2,1 & 2136,1 & 2,3 \\
\hline Opening Bank & 2965,9 & 3,6 & 2677,8 & 3,3 & 1766,8 & 2,1 & 1392,9 & 1,5 \\
\hline UniCredit Bank & 1375,1 & 1,7 & 1148,0 & 1,4 & 1178,2 & 1,4 & 1357,6 & 1,4 \\
\hline Promsvyazbank & 1218,2 & 1,5 & 1252,3 & 1,6 & 993,8 & 1,2 & 1257,0 & 1,3 \\
\hline Raiffeisenbank & 851,1 & 1,0 & 752,7 & 0,9 & 837,8 & 1,0 & 1115,2 & 1,2 \\
\hline ROSBANK & 861,3 & 1,0 & 758,4 & 0,9 & 924,2 & 1,1 & 1082,3 & 1,2 \\
\hline SICI total & 48895,3 & 58,9 & 47413,7 & 59,2 & 51162,4 & 60,1 & 61589,3 & 65,5 \\
\hline Total banking sector & 82999,7 & 100,0 & 80063,3 & 100,0 & 85191,8 & 100,0 & 94083,7 & 100,0 \\
\hline
\end{tabular}

Table 1 show that the share of SICI assets in the banking sector is growing. In 2016-2018, the indicator increased by 6.6 points or $11 \%$, which was influenced by the launch of PAO Credit Bank of Moscow in the category of systemically important credit institutions. Excluding the assets of this Commercial Bank, the share of SICI assets in the banking sector at the beginning of 2018 would be $57.9 \%$, which is lower than at the beginning of 2016 and 2017. By the beginning of 2019, even without the assets of PAO Credit Bank of Moscow, the share of SICI assets would be higher than at the beginning of 2018 (63.2\%). In other words, we can say that in 2018 all SICIs were able to increase their assets and increase their importance in the banking sector.

The only SICI, the assets of which declined annually, was PAO Opening Bank. In 2016-2018, the assets of PAO Opening Bank decreased by 1,573 bln rub or 53\%. In 2017, issues in the activities of another Bank (PAO Promsvyazbank) were also determined, this Bank's assets for 2017 decreased by $258.5 \mathrm{bln}$ rub, while the other SICI's assets increased in 2017. In 2018, the issues of PAO Promsvyazbank were partially solved, since this Bank has already seen an increase in assets, as well as the majority of systemically important banks. Although if we consider the three-year dynamics, it should be noted that only PAO VTB, AO Rosselkhozbank and AO Alfa-Bank had annual growth in assets, therefore, the assets of five banks decreased in 2016. AO Alfa-Bank (56.2\%) and PAO VTB (45.2\%) had the highest growth rates of assets in 2016-2018.

As for the structural part of the analysis, Sberbank's assets have accounted for more than a quarter of all banking sector assets over the past three years. Next in the asset structure are PAO VTB (about 11-12\%, at the end of 2018 and $14.5 \%$ in 2018, due to the accession of PAO VTB 24) and AO Gazprombank (about 6-6.5\%), then the gaps are not so significant.

The decline in SICI assets in 2016 was a key reason for the decline in assets of the domestic banking sector, as was the growth in assets in 2017 and 2018. In other words, trends in asset changes in the activities of systemically important banks have an impact on trends in the assets of the entire banking sector. Moreover, by accumulating SICI assets and calculating the growth rate for 2016-2018, we can conclude that the assets grew by $12694,1 \mathrm{bln}$ rub, or $26 \%$, while banking sector assets for the same period increased by $11084 \mathrm{bln}$ rub, or $13.4 \%$. That is, for the period from 2016 to 2018 the assets of systemically important banks outpaced the growth of assets of all Russian credit institutions.

The following indicator is estimated in the same way - the placed SICI funds in credit and financial organizations. Table 2 demonstrates the dynamics of SICI funds placed in credit and financial institutions based on 101 reporting form, as well as the dynamics of the indicator in the banking sector in total. 
Table 2. Systemically important banks placed funds dynamics in financial and credit organizations (Overview of the banking sector of the Russian Federation \& Financial statements of Russian banks)

\begin{tabular}{lllllllll}
\hline \multirow{2}{*}{$\begin{array}{l}\text { Name of the credit } \\
\text { institution }\end{array}$} & \begin{tabular}{l}
01.01 .2016 \\
\cline { 2 - 9 } \\
\cline { 2 - 9 } \\
bolume, rub
\end{tabular} & $\begin{array}{l}\text { Share } \\
, \%\end{array}$ & $\begin{array}{l}\text { Volume, } \\
\text { bln rub }\end{array}$ & $\begin{array}{l}\text { Share } \\
, \%\end{array}$ & $\begin{array}{l}\text { Volume, } \\
\text { bln rub }\end{array}$ & $\begin{array}{l}\text { Share } \\
, \%\end{array}$ & $\begin{array}{l}\text { Volume, } \\
\text { bln rub }\end{array}$ & $\begin{array}{l}\text { Share, } \\
\%\end{array}$ \\
\hline Sberbank & 3150,6 & 19,3 & 3145,2 & 18,2 & 3311,3 & 16,5 & 3450,9 & 16,7 \\
\hline VTB & 2309,7 & 14,2 & 1648,8 & 9,6 & 1604,4 & 8,0 & 1892,0 & 9,2 \\
\hline Gazprombank & is not systematically significant & & 923,0 & 4,6 & 1125,5 & 5,5 \\
\hline Rosselkhoznadzor & 270,1 & 1,7 & 342,0 & 2,0 & 699,9 & 3,5 & 1071,4 & 5,2 \\
\hline Alfa-bank & 258,2 & 1,6 & 413,0 & 2,4 & 554,9 & 2,8 & 697,1 & 3,4 \\
\hline Moscow credit bank & 216,9 & 1,3 & 202,9 & 1,2 & 342,0 & 1,7 & 396,8 & 1,9 \\
\hline Opening Bank & 207,8 & 1,3 & 284,3 & 1,6 & 207,3 & 1,0 & 390,6 & 1,9 \\
\hline UniCredit Bank & 356,7 & 2,2 & 309,1 & 1,8 & 292,4 & 1,5 & 353,8 & 1,7 \\
\hline Promsvyazbank & 502,9 & 3,1 & 591,8 & 3,4 & 597,8 & 3,0 & 343,5 & 1,7 \\
\hline Raiffeisenbank & 348,4 & 2,1 & 735,4 & 4,3 & 680,1 & 3,4 & 297,9 & 1,4 \\
\hline ROSBANK & 164,3 & 1,0 & 137,9 & 0,8 & 154,6 & 0,8 & 137,0 & 0,7 \\
\hline SICI total & 7785,6 & 47,8 & 7810,4 & 45,3 & 9367,6 & 46,8 & 10156,6 & 49,3 \\
\hline Total banking sector & 16287,7 & 100,0 & 17238,6 & 100,0 & 20022,0 & 100,0 & 20604,2 & 100,0 \\
\hline
\end{tabular}

Analyzing the banks' connection indicates in terms of funds placed in financial and credit institutions, we notice that the SICI share in the structure of the banking sector accounts for $45.3 \%$ to $49.3 \%$ in the analyzed periods. However, if PAO Credit Bank of Moscow had not been included in the SICI in 2017, there would have been a decrease in the share of the studied indicator from $47.8 \%$ at the beginning of 2016 to $43.8 \%$ by the beginning of 2019 . The volume of funds placed on accounts and in the form of loans in financial and credit organizations of systemically important banks grew annually, the same trend is observed in the banking sector. In 2016-2018, the indicator for the North-West Bank increased by 2,371 bln rub or $30.5 \%$, while the growth in the banking sector was $4,316.5$ bln rub or $26.5 \%$ over the same period.

Only AO Gazprombank and AO Alfa-Bank reached annual progress in the funds volume placed in financial and credit institutions during the period under review. At least once during the period, the rest of the SICIs saw a decrease in the number of funds placed. The analysis of dynamics for three years showed a decrease in the indicator for PAO VTB, AO Rosselkhozbank, PAO Opening Bank, AO UniCredit Bank, and AO Raiffeisenbank. Therefore, the other five banks (except PAO Credit Bank of Moscow) had an increase in the indicators for 2016-2018.

The analysis of the dynamics and structure of the third indicator - attracted SICI funds from financial and credit organizations is presented in Table 3 .

Table 3. SICI attracted funds dynamics (Overview of the banking sector of the Russian Federation \& financial statements of Russian banks)

\begin{tabular}{|c|c|c|c|c|c|c|c|c|}
\hline \multirow{2}{*}{$\begin{array}{l}\text { Name of the credit } \\
\text { institution }\end{array}$} & \multicolumn{2}{|c|}{01.01 .2016} & \multicolumn{2}{|c|}{01.01 .2017} & \multicolumn{2}{|c|}{01.01 .2018} & \multicolumn{2}{|c|}{01.01 .2019} \\
\hline & $\begin{array}{l}\text { Volume, } \\
\text { bln rub }\end{array}$ & Share, $\%$ & $\begin{array}{l}\text { Volume, } \\
\text { bln rub }\end{array}$ & Share, $\%$ & $\begin{array}{l}\text { Volume, } \\
\text { bln rub }\end{array}$ & Share, $\%$ & $\begin{array}{l}\text { Volume, } \\
\text { bln rub }\end{array}$ & Share, $\%$ \\
\hline Sberbank & 1390,0 & 10,5 & 961,4 & 7,9 & 1067,5 & 8,9 & 1568,2 & 12,4 \\
\hline VTB & 3193,9 & 24,1 & 2654,6 & 21,9 & 1855,0 & 15,4 & 1401,2 & 11,1 \\
\hline Gazprombank & \multicolumn{4}{|c|}{ is not systematically significant } & 629,5 & 5,2 & 534,8 & 4,2 \\
\hline Rosselkhoznadzor & 465,3 & 3,5 & 398,1 & 3,3 & 316,6 & 2,6 & 345,5 & 2,7 \\
\hline
\end{tabular}




\begin{tabular}{lllllllll}
\hline Alfa-bank & 1658,1 & 12,5 & 1077,4 & 8,9 & 648,7 & 5,4 & 261,3 & 2,1 \\
\hline Moscow credit bank & 207,8 & 1,6 & 272,3 & 2,2 & 191,5 & 1,6 & 211,7 & 1,7 \\
\hline Opening Bank & 198,7 & 1,5 & 176,9 & 1,5 & 93,2 & 0,8 & 187,1 & 1,5 \\
\hline UniCredit Bank & 130,0 & 1,0 & 101,1 & 0,8 & 76,3 & 0,6 & 128,2 & 1,0 \\
\hline Promsvyazbank & 109,7 & 0,8 & 56,0 & 0,5 & 52,0 & 0,4 & 86,7 & 0,7 \\
\hline Raiffeisenbank & 180,4 & 1,4 & 155,0 & 1,3 & 111,0 & 0,9 & 82,0 & 0,6 \\
\hline ROSBANK & 209,9 & 1,6 & 121,2 & 1,0 & 388,2 & 3,2 & 73,4 & 0,6 \\
\hline SICI total & 7743,7 & 58,4 & 5974,1 & 49,3 & 5429,5 & 45,0 & 4880,1 & 38,5 \\
\hline Total banking sector & 13255,3 & 100,0 & 12113,6 & 100,0 & 12056,6 & 100,0 & 12677,2 & 100,0 \\
\hline
\end{tabular}

The SICIs share in the banking sector accounts for $38.5 \%$ to $58.4 \%$ over the past three years, but their share in the dynamics is decreasing. Excluding the share of PAO Credit Bank of Moscow in 2017, the share in the banking sector would have been $39.2 \%$ by the beginning of 2018 , and $34.3 \%$ by the beginning of 2019 . The reason for the decrease in the share of SSCS in the banking sector is an absolute decrease in the indicator. At the same time, until 2018, there was an absolute decrease in the indicator for the banking sector as a whole. However, the decrease rate in funds raised from credit institutions in 2016-2018 for SICIs are higher (37\%) than for the banking sector (4.4\%).

In the SICI context, the annual decrease in attracted resources was observed in PAO VTB (for three years the rate of decline was 56.1\%), PAO Opening Bank (the rate of decline was 84.2\%) and AO UniCredit Bank (the rate of decline was 54.5\%). At the same time, none of the SICIs has seen an annual increase in funds raised from credit institutions. If we consider the three-year dynamics of the indicator, the growth is observed only in PAO Sberbank (12.8\%) and AO Alfa-Bank (1.1\%), while the indicator for the rest of the SICIs decreased in 2016-2018.

We note that in contrast to the first two indicators that were analyzed above, PAO VTB took the lead in attracting funds from banks among systemically important banks during 2016-2017, and only from the beginning of 2019, Sberbank took the lead. PAO Credit Bank of Moscow is also active in this segment, taking a confident 3rd position among SICIs by the beginning of 2019, which allows noting that it is active in operations with credit organizations, both in terms of placing funds and attracting funds.

The fourth indicator to determine the status of the Bank and the possibility of its inclusion in the category of systemically important is the volume of population deposits (Table 4).

Table 4. Dynamics of SICIs population deposits Overview of the banking sector of the Russian Federation \& Directory of credit organizations)

\begin{tabular}{|c|c|c|c|c|c|c|c|c|}
\hline \multirow{2}{*}{$\begin{array}{l}\text { Name of the credit } \\
\text { institution }\end{array}$} & \multicolumn{2}{|c|}{01.01 .2016} & \multicolumn{2}{|c|}{01.01 .2017} & \multicolumn{2}{|c|}{01.01 .2018} & \multicolumn{2}{|c|}{01.01 .2019} \\
\hline & $\begin{array}{l}\text { Volume, } \\
\text { bln rub }\end{array}$ & Share, $\%$ & $\begin{array}{l}\text { Volume, } \\
\text { bln rub }\end{array}$ & Share, \% & $\begin{array}{l}\text { Volume, } \\
\text { bln rub }\end{array}$ & Share, \% & $\begin{array}{l}\text { Volume, } \\
\text { bln rub }\end{array}$ & Share, $\%$ \\
\hline Sberbank & 10221,3 & 44,0 & 10937,7 & 45,2 & 11777,4 & 45,3 & 12911,2 & 45,4 \\
\hline VTB & 44,1 & 0,2 & 539,6 & 2,2 & 624,5 & 2,4 & 3890,3 & 13,7 \\
\hline Gazprombank & 624,5 & 2,7 & 680,9 & 2,8 & 843,6 & 3,2 & 1122,4 & 3,9 \\
\hline Rosselkhoznadzor & 498,0 & 2,1 & 624,4 & 2,6 & 874,7 & 3,4 & 1059,3 & 3,7 \\
\hline Alfa-bank & 631,1 & 2,7 & 659,0 & 2,7 & 821,2 & 3,2 & 969,0 & 3,4 \\
\hline Moscow credit bank & 363,2 & 1,6 & 354,6 & 1,5 & 392,5 & 1,5 & 471,4 & 1,7 \\
\hline Opening Bank & 248,9 & 1,1 & 520,5 & 2,2 & 424,4 & 1,6 & 466,7 & 1,6 \\
\hline UniCredit Bank & 268,7 & 1,2 & 393,0 & 1,6 & 356,7 & 1,4 & 382,4 & 1,3 \\
\hline Promsvyazbank & is not sys & matically s & snificant & & 285,0 & 1,1 & 368,3 & 1,3 \\
\hline Raiffeisenbank & 196,8 & 0,8 & 204,9 & 0,8 & 244,0 & 0,9 & 280,2 & 1,0 \\
\hline
\end{tabular}




\begin{tabular}{lllllllll}
\hline ROSBANK & 176,8 & 0,8 & 169,9 & 0,7 & 218,5 & 0,8 & 246,8 & 0,9 \\
\hline SICI total & 13273,5 & 57,2 & 15084,6 & 62,3 & 16862,5 & 64,9 & 22168,0 & 77,9 \\
\hline Total banking sector & 23219,1 & 100,0 & 24200,3 & 100,0 & 25987,4 & 100,0 & 28460,2 & 100,0 \\
\hline
\end{tabular}

For 2016-2018, there was an increase in the share of SICIs deposits in the total volume of deposits in the banking sector, the indicator grew by $36.3 \%$ and at the beginning of 2019, the share of SICI deposits accounted for $77.9 \%$. A certain jump in the indicator occurred due to the fact that PAO Credit Bank of Moscow was recognized as a systemically important Bank in September 2017, and PAO VTB 24 also joined in 2018. Bank's indicator has grown naturally, but even if not the deposits of the population for these two banks, there is a relative increase in the indicator for systemically important banks.

Deposits grew annually both in the banking sector as a whole and in systemically important banks. The significant increase in deposits in comparison with the banking sector is most likely due to the fact that Bank customers whose licenses were revoked and canceled were transferred to more stable and reliable credit institutions, which are systemically important banks.

With regard to the structure, it should be noted that, in contrast to the size and connections of the deposits, a huge share of individuals' funds is concentrated in Sberbank. The largest Bank of Russia accounts for about $45 \%$ of the total volume of deposits placed in the banking sector. And the gap with the other Bank is quite significant. PAO VTB takes the $2^{\text {nd }}$ place with a specific share of $13.7 \%$ by the beginning of 2019 , then the indicators of the three systemically important banks are approximately the same (from $3.4 \%$ to $3.9 \%$ ).

\section{Summary}

First, concerning the size of SICIs, it is worth mentioning that their scale of activity plays a crucial role in the banking sector functioning of the Russian Federation. Hence, the trends in the development of their assets directly affect the trends in the assets of the entire banking sector. (Bulatova et al., 2019). Nevertheless, this does not mean that SICIs are free from any issues since, in 2017, the two largest banks - PAO Promsvyazbank and PAO Opening Bank announced significant problems in their operations. Therefore, to maintain the stability of the banking system, the Bank of Russia set out to sanitize these banks.

Secondly, about deposits of the population, there is a rise in the volume of attracted resources from individuals for all systemically important banks.

Simultaneously, SICIs individual deposits could expand both naturally, due to the influx of new customers or replenishment of amounts on existing deposits, and artificially. Only AO UniCredit Bank and PAO Credit Bank of Moscow are not agents of the Deposit Insurance Agency out of the 11 systemically significant banks that exist today. Regarding the negative dynamics of the population's deposits in 2017 in two credit institutions sanitized by the Bank of Russia, the reason for this is a rather psychological effect. Due to the low financial literacy of the vast majority of clients, Bank counterparties decided to withdraw their funds from Deposit, settlement, and card accounts and place them in other banks.

Thirdly, until the start of 2018, the share of systemically important banks in the banking sector was higher for attracted funds than for placed ones. Even so, the drop in the share of funds raised from banks demonstrates that systemically important banks have found other ways to attract resources in the dynamics and are gradually reducing their dependence on interbank sources. However, at the same time, they are increasing the volume of funds placed in credit and financial organizations, which indicates the provision of financial support for credit organizations.

\section{Conclusions}

To sum up, we can conclude that the many root causes identified in the global financial system demonstrate the importance of regulating and controlling systemically important financial institutions (Bulatova et al., 2019). The Central Bank of the Russian Federation took special control of Russian systemically important banks, switched to new regulatory principles, and entered into force new international requirements of Basel. The regulation of SICIs is complex and is determined by supranational and national levels, which, interacting with each other, can create a solid system for managing SICI processes.

In general, systemically important banks dominate the banking sector by most indicators. Moreover, in most of them, there is an increase in the studied indicators in dynamics, the share of systemically important banks on deposits of the population and assets accounts for $60 \%$ to $78 \%$ of banking sector operations. Sberbank, which accounts for a third of 
the countries banking market, naturally plays a huge role in the structure of systemically important banks (Shaidullin et al., 2019). Consequently, the position of the banking sector largely depends on its stability. However, there are also negative results, as shown by the analysis of the problem of PAO Opening Bank and PAO Promsvyazbank, that can shake the already unstable position of the banking sector. In order to better assess the problems of systemically important banks, we will further analyze the stability and reliability of system banks.

\section{Acknowledgments}

The work is performed according to the Russian Government Program of Competitive Growth of Kazan Federal University.

\section{References}

Bulatova, E. I., Potapova, E. A., Fathutdinova, R. A., \& Yandiev, R. C. (2019). Monitoring and Controlling Banking System via Financial Stability Assessment.

Bulatova, E. I., Potapova, E. A., Fathutdinova, R. A., \& Yandiev, R. Ch. (2019). Financial stability assessment as a tool for monitoring and controlling banking system.

Bulatova, E., Duvalova, J., Duvalova, E., \& Khafizova, A. (2019). Interaction of the banking and real economy sectors in the regional aspect.

Directory of Credit Organizations. (n.d.). Retrieved from http://www.cbr.ru/credit/main.asp

Financial Statements of Russian Banks. (n.d.). Retrieved from https://www.bankodrom.ru/finansovaya-otchetnost-bankov-rossii/

Kahraman, U. A. (2020). Selection of suitable bank based on quality of providing systems for internet banking services using AHP and ANP methods. Journal of Management and Accounting Studies, 8(4), 50-60.

On the method of determining systemically significant credit organizations (n.d.). Federal law of 22.07.2015, No. 3737-U// Legal reference system "Consultant Plus".

Overview of the banking sector of the Russian Federation. (n.d.). Retrieved from http://www.cbr.ru/analytics/?PrtId=bnksyst

Shaidullin, R., Bulatova, E., Kurmanova, L., Khabibullin, R., \& Zhuzhoma, J. (2019). Evaluation of financial stability of Russian companies. In E3S Web of Conferences (Vol. 110, p. 02044). EDP Sciences.

\section{Copyrights}

Copyright for this article is retained by the author(s), with first publication rights granted to the journal.

This is an open-access article distributed under the terms and conditions of the Creative Commons Attribution license (http://creativecommons.org/licenses/by/4.0/). 